\title{
Peningkatan Motivasi Kewirausahaan Para Pelaku Usaha di Desa Warnasari Kecamatan Pangalengan Kabupaten Bandung
}

\author{
Abdul Rosid', Atin Hafidiah2, Yuyun Yuniarti ${ }^{3}$, Dindin Abdurrohim ${ }^{4}$ \\ ${ }^{1}$ Ilmu Administrasi Bisnis, Universitas Pasundan \\ 2 Ilmu Administrasi Bisnis, Universitas Pasundan \\ ${ }^{3}$ Ilmu Administrasi Bisnis, Universitas Pasundan \\ ${ }^{4}$ Ilmu Administrasi Bisnis, Universitas Pasundan \\ Email: 1abdul.rosid@unpas.ac.id, 2atin.hafidiah@unpas.ac.id, 3yuyun.yuniarti@unpas.ac.id, \\ $\underline{4}$ dindin.abdulrochim@unpas.ac.id
}

\begin{abstract}
Abstrak
Penduduk Desa Warnasari pada umumnya, dikenal dalam komoditi sayur mayur dan peternak sapi perah, juga memproduksi teh hijau/merah merupakan produksi andalan dari daerah ini. Analisis kondisi eksisting yang terdapat di Desa Warnasari dapat diidentifikasi permasalahan-permasalahan yang dihadapi yang berkaitan dengan minat dalam menumbuhkan kewirausahaan yakni; adanya permasalahan yang berkaitan dengan wirausaha, berkaitan dengan motivasi untuk menumbuhkan minat berwirausaha, berkaitan dengan tidak berkembangnya wirausaha, berkaitan dengan pemanfaatan dan pengembangan potensi diri dan potensi Sumber Daya Alam yang dimiliki (perkebunan, perikanan, peternakan). Seluruh peserta dikumpulkan dalam satu ruangan, selanjutnya peserta menerima materi, kemudian peserta diberikan kesempatan untuk mengajukan pertanyaan-pertanyaan yang berkaitan dengan kewirausahaan, motivasi/menumbuhkan minat berwirausaha serta strategi sukses berwirausaha, yakni kemampuan untuk berbuat sesuatu, mempunyai semangat, sikap, dan kemampuan dalam menangani usaha dan kegiatan yang mengarah kepada upaya mencari, menciptakan, menerapkan cara kerja, dengan meningkatkan efesiensi dalam rangka memberikan pelayanan yang lebih baik atau keuntungan yang lebih besar.
\end{abstract}

Kata Kunci: Motivasi, Kewirausahaan, Warnasari.

\begin{abstract}
Residents of Warnasari Village in general, are known in vegetable commodities and Dairy Cattle farmers, also producing green/red tea is the mainstay production of this region: Analysis of the existing conditions in Warnasari Village, problems can be identified that are related to interest in growing entrepreneurship, namely, the existence of problems related to entrepreneurship, the existence of problems related to motivation to foster interest in entrepreneurship, related to the development of entrepreneurship, related by utilizing and developing the of Natural Resources owned by the farm. (plantation, fisheries, this method all participants are collected in one room, then participants receive the material, then participants are given the opportunity to submit questions related to entrepreneurship, motivation/foster interest in entrepreneurship and entrepreneurial success strategy In terms of motivation and successful entrepreneurial strategies, namely the ability to do something, have enthusiasm, attitude, and ability to handle business and activities that lead to efforts to find, create, implement ways to improve efficiency in order to provide better services or greater benefits of work.
\end{abstract}

Keywords: Motivation, Entrepreneurship, Warnasari 


\section{PENDAHULUAN}

Kondisi perekonomian masyarakat yang harus mendapat perhatian dari pemerintah Kabupaten Bandung, adalah bagaimana memajukan dan meningkatkan usaha kecil dan menengah termasuk para pengarajin yang ada di Kabupaten Bandung untuk lebih maju dan kondusif, terutama tingkat kesejahteraan masyarakat Kabupaten Bandung yang berusaha di sektor informal, khususnya dalam usaha kecil dan menengah yang selama ini hidup kurang adanya motivasi dan semangat untuk mengembangkan dan menumbuhkan jiwa wirausaha yang perlu diperhatikan dalam keberadaannya, sehingga mereka dapat memperoleh kesejehateraan hidupnya yang lebih baik. Mereka kurang mampu dan mau menciptakan lapangan kerja sendiri. Bahkan untuk kasus di Indonesia hal itu masih terjadi sampai sekarang.

Kita perlu perhatian dengan rendahnya minat wirausaha di kalangan para pemuda/karang taruna, dan ibu-ibu PKK serta masyarakat pada umumnya di desa-desa dan juga para lulusan sekolah dari tingkat SMP, SMA sampai Perguruan Tinggi. (Hasil P3M Fisip Unpas: Yayan Mulyana dkk.). Namun kita tidak perlu menyalahkan siapapun. Inilah kesempatan untuk mendorong para pelaku usaha, untuk lebih termonivasi dalam menjalankan usaha atau berwirausaha dengan mengembangkan potensi/kemampuan diri dan potensi Sumber Daya Alam yang dimiliki (hasil bumi/perkebunan, perikanan dan peternakan) yang ada di masyarakat setempat. Bagaimana kita dapat merubah pola pikir di lingkungan masyarakat yang selalau berkeinginan untuk menjadi karyawan/pegawai, dengan cara bagaimana merubah pola pikir dan bertindak untuk dapat menciptakan lapangan kerja sendiri dengan menumbuhkan dan mengembangkan serta meningkatkan motivasi untuk berwirausaha dikalangan para pelaku usaha di Desa Warnasari Kecamatan Pangalengan Kabupaten Bandung.

Kesuksesan dalam dunia wirausaha, tentunya dibangun dan diberikan semangat dengan harapan dan impian serta konsisten dalam menggapainya. Kesuksesan tersebut tentunya tidak terbatas dalam aspek lingkungan pekerjaan, bisnis, profesi, maupun sebagai karyawan. Kesuksesan itu dibangun atas dasar komitmen diri sendiri dan cita-cita yang selama ini menjadi impian. Pada kegiatan Pengabdian Kepada Masyarakat (PKM) ini, Tim memfokuskan pada sasaran (mitra) untuk melakukan Pelatihan Peningkatan Motivasi para Pelaku Usaha di Desa Warnasari Kecamatan Pangalengan Kabupaten Bandung. Mengingat bahwa objek ini telah dijadikan desa binaan oleh P3M Fisip Unpas.

\section{METODE PELAKSANAAN}

Kegiatan ini dalam pelaksanaannya, menggunakan Metode obsevasi, wawancara ceramah dan tanya jawab, dimana dalam metode ini seluruh peserta dikumpulkan dalam satu ruangan, selanjutnya peserta menerima materi yang disampaikan oleh Nara Sumber, kemudian peserta diberikan kesempatan untuk mengajukan pertanyaan-pertanyaan yang berkaitan dengan kewirausahaan, motivasi atau menumbuhkan minat berwirausaha serta strategi sukses berwirausaha.

Tahapan kegitan ini terbagi kepada 3 (tiga) tahap:

1. Persiapan, pada tahap ini diidentifikasi, menyeleksi, serta mengelompokan calon perserta. Selanjutnya Tim menyiapkan tempat, sarana, nara sumber/trainer dan menyusun pola program dan training yang tepat dan hasil guna.

2. Pelaksanaan, melalui Training, yaitu memberikan wawasan dan pengetahuan kepada peserta tentang bagaimana merubah pola pikir pekerja menjadi pengusaha, motivasi timbul niat dan minat serta bagaimana 
membangun wirausaha pada diri peserta, serta kunci sukes dalam menjalankan usaha.

3. Evaluasi, dilakukan untuk mengkaji atau menilai pelaksanaan kegiatan dengan tujuan untuk memperbaiki atau menyempurnakan kegiatan. Pada tahap evaluasi dilakukan pada saat masih berlangsung (formatif) serta saat kegiatan ini sudah berakhir (sumatif).

\section{HASIL DAN PEMBAHASAN}

Desa Warnasari merupakan bagian dari Kecamatan Pangalengan Kabupaten Bandung Provinsi Jawa Barat. Desa Warnasari memiliki luas wilayah 2.354,119 hektar, terletak pada ketinggian $\pm 1442 \mathrm{mdpl}$ dan memiliki suhu udara rata-rata $12{ }^{\circ} \mathrm{C}-25^{\circ} \mathrm{C}$. Batas wilayah Desa Warnasari adalah : Sebelah utara : Desa Pulosari Sebelah timur : Desa Pulosari Sebelah selatan : Desa Margaluyu Sebelah barat : Kecamatan Pasir Jambu 64 Desa Warnasari memiliki 17 Rukun Warga dan 17 kampung yaitu Baru Taraje, Ciawitali, Cibeunying, Cibunihayu, Cidurian, Cipangisikan, Citiis, Kapas, Kiaracondong, Munjul, Neglasari, Padahurip, Palayangan, Parabon, Pasir Ucing, Singkur, dan Wanasari. Lokasi TPK Warnasari berada didepan Jalan utama Desa Warnasari di RW 02 Kampung Wanasari berjarak \pm 300 meter ke sebelah barat dari kantor Desa Warnasari. Penempatan TPK Warnasari yang terletak di lokasi pusat desa mudah dijangkau oleh para peternak di daerah utara dan selatan serta memudahkan truk untuk mendistribusikan susu yang dikumpulkan peternak ke lokasi industri pengolahan susu (PT. Frissian Flag).

Pola guna lahan berdasarkan Monografi Desa Warnasari pada tahun 2018, Tata guna lahan Desa Warnasari adalah sebagai berikut :

Tabel 1. Tata Guna Lahan Desa Warnasari Kecamatan Pangalengan Kab. Bandung

\begin{tabular}{cccc}
\hline No & Kegunaan & Luas & Jumlah \\
& Lahan & Lahan & $(\%)$ \\
& $(\mathrm{Ha})$ & \\
& & \\
\end{tabular}

\begin{tabular}{cccc}
\hline 1. & Pemukiman & 51,003 & 2,17 \\
\hline 2. & Perkebunan & 314,610 & 13,37 \\
\hline 3. & Fasilitas Umum & 198,610 & 8,44 \\
\hline 4. & Ladang/Tegal & 437,561 & 18,58 \\
\hline 5. & Perhutanan & 1352,335 & 57,44 \\
\hline Total Luas Lahan & 2354,119 & 100,00
\end{tabular}

Sumber : Monografi Desa Warnsari Tahun 2018

Tabel 1 menunjukkan bahwa luas lahan yang terbesar yaitu lahan perhutanan seluas 1.352 Hektar $(57,44 \%)$. Lahan perhutanan biasa dimanfaatkan oleh para peternak untuk mencari pakan hijauan rumput terutama ketika musim kemarau. Luas pemukiman sebesar 51,003 Ha ditempati oleh 2.613 kepala keluarga dengan total penduduk 8.748 jiwa yang terdiri dari 4.396 laki-laki dan 4.352 perempuan.

Mata pencaharian warga desa Warnasari pada tahun 2018 disajikan sebagai berikut :

Tabel 2. Mata Pencaharian Penduduk Desa Warnasari, Kecamatan Pangalengan Kab. Bandung

\begin{tabular}{|c|c|c|c|c|c|}
\hline No & $\begin{array}{c}\text { Jenis } \\
\text { pekerjaan }\end{array}$ & Jenis & $\begin{array}{l}\text { Kela } \\
\text { min }\end{array}$ & $\begin{array}{c}\text { Juml } \\
\text { ah }\end{array}$ & $\begin{array}{c}\text { Persen } \\
\text { tase }\end{array}$ \\
\hline 1. & Petani & 421 & 97 & 520 & 15,21 \\
\hline 2. & $\begin{array}{c}\text { Buruh } \\
\text { Tani }\end{array}$ & 867 & 681 & 1548 & 45,40 \\
\hline 3. & $\begin{array}{c}\text { Pegawai } \\
\text { Negeri } \\
\text { Sipil }\end{array}$ & 12 & 14 & 26 & 0,77 \\
\hline 4. & $\begin{array}{c}\text { Pengrajin } \\
\text { Industri } \\
\text { Rumah } \\
\text { Tangga }\end{array}$ & 19 & 43 & 62 & 1,81 \\
\hline 5. & $\begin{array}{l}\text { Pedagan } \\
\text { g Keliling }\end{array}$ & 228 & 129 & 357 & 10,47 \\
\hline 6. & Peternak & 394 & 21 & 415 & 12,17 \\
\hline 7. & Lainnya & 222 & 261 & 483 & 14,17 \\
\hline & Total & 2163 & 1248 & 3411 & 100,00 \\
\hline
\end{tabular}


Tabel 2 menunjukkan bahwa mayoritas masyarakat desa Warnasari bekerja sebagai buruh tani dengan jumlah jiwa sebanyak 1.548 $(45,40 \%)$.

Kegitan Pengabdian Kepada Masyarakat di Desa Warnasar Kecamatan Pangalengan dijadwalkan selama 4 (empat) bulan : Bulan ke 1 (Januari) Persiapan, Bulan ke 2 (Februari) Pelaksanaaan/Pelatihan, Bulan ke 3 (Maret) Pelaporan/penyusunan draft laporan dan penyempurnaan laporan akhir, Bulan ke 4 (April) Penyerahan laporan akhir dan Penulisan artikel ilmiah. Adapun pelaksanaan pelatihannya kepada audiensi atau pelaku usaha bertempat di Pesantren Al Azhar Desa Warnasari Kecamatan Pangalengan dilaksanakan pada bulan Februari 2019 mengenai Pelatihan Menumbuhkan Minat wirausaha pada Karang Taruna, Ibu-ibu PKK, dan Pengrajin di Desa Warnasari Kecamatan Pangalengan Kabupaten Bandung. Menumbuhkan minat usaha dan memulai usaha baru oleh Drs. H. Abdul Rosid, MSi, Motivasi dan strategi sukses berwirausaha oleh Dr. Dindin Abdurrohim, S.Sos.,MSi, membuat laporan keuangan dan perpajakan oleh Dra. Atin Hafidiah, MSi. dan Etika Bisnis dan Pengembangan SDM oleh Dr. Yuyun Yuniarti, MSi.

Secara umum dalam pelatihan ini dengan memotivasi wirausaha berupa pengarahan dan ceramah disertai dengan contoh-contoh dan gambaran para pengusaha sukses yang dimulai dari kecil sehingga bisa menjadi pengusaha besar, semua itu dilakukan dengan proses yang cukup lama dan berat (Dindin Abdurrohim 2018). Menjadi seorang wirausaha diawali karena ingin terjun menjadi pengusaha, karena iseng-iseng, karena coba-coba dan karena terpaksa.. Begitupun dalam penyampaian materi pelatihan dalam motivasi dan strategi berwirausaha sukses dengan mendorong para pelaku usaha ini dengan memberikan gambaran bahwa potensi penghasilan tidak terbatas, memaksimalkan potensi yang dimiliki, sikap mental yang mandiri, kepuasan atas keberhasilan dan lebih jauh dari itu dapat memberikan kontribusi bagi masyarakat, disamping untuk meningkatkan kesejahteraan keluarga.

Pelaku usaha diharapkan dapat meningkatkan kreativitas dan inovasi ketika dihadapkan kepada situasi dan kondisi yang tidak menentu dalam arti kegiatan usaha yang fluktuatif dimasa-masa sekarang ini. Hal terdebut dapat dilakukan dengan kegiatan jangka pendek, jangka menengah dan jangka panjang dalam melakukan inovasi baik dari aspek pengembangan produk, pemasaran, peningkatan dan pengembangan sumber daya manusia dalam mengelola sumber daya alam yang dimiliki di Desa Warnasari Kecamatan Pangalengan Kabupaten Bandung.

Sebagaimana rencana yang telah dibuat bahwa kegiatan pelatihan ini dalam melaksanakan kegiatan Pengabdian Kepada Masyarakat diawali dengan kegiatan observasi atau survey lapangan, wawancara dengan aparat desa dan terutama dengan pelaku usaha untuk mengetahui permasalahan dan potensi usaha yang dikembangkan.

Kegiatan pelatihan untuk memulai usaha, yaitu ada beberapa faktor: Faktor keluarga pengusaha, sengaja terjun menjadi pengusaha, kerja sampingan (iseng), coba-coba, terpaksa. Dalam hal motivasi dan strategi sukses berwirausaha, materi yang diberikan yakni kemampuan untuk berbuat sesuatu, mempunyai semangat, sikap, dan kemampuan dalam menangani usaha dan kegiatan yang mengarah kepada upaya mencari, menciptakan, menerapkan cara kerja, teknologi dan produk baru dengan meningkatkan efesiensi dalam rangka memberikan pelayanan yang lebih baik atau keuntungan yang lebih besar. 


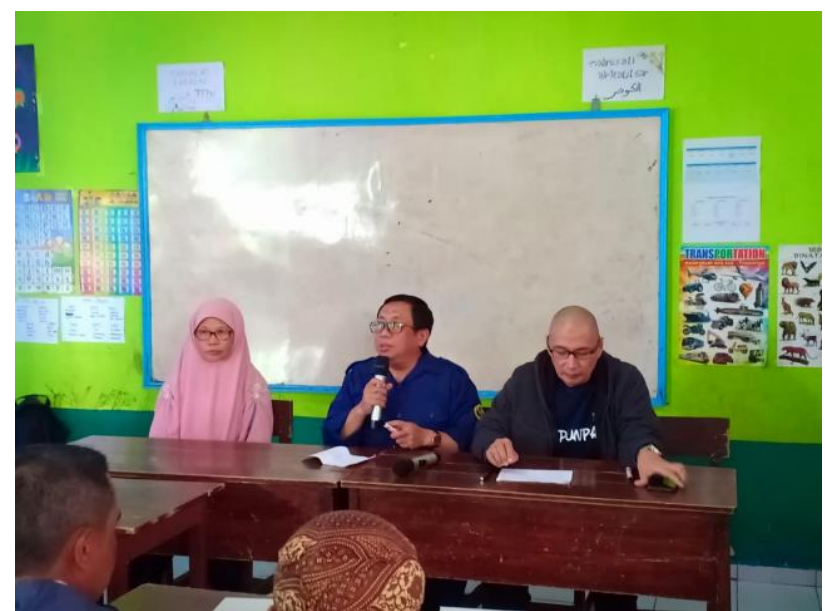

Gambar 1. Pelatihan Kewirausahaan UKM Desa Warnasari

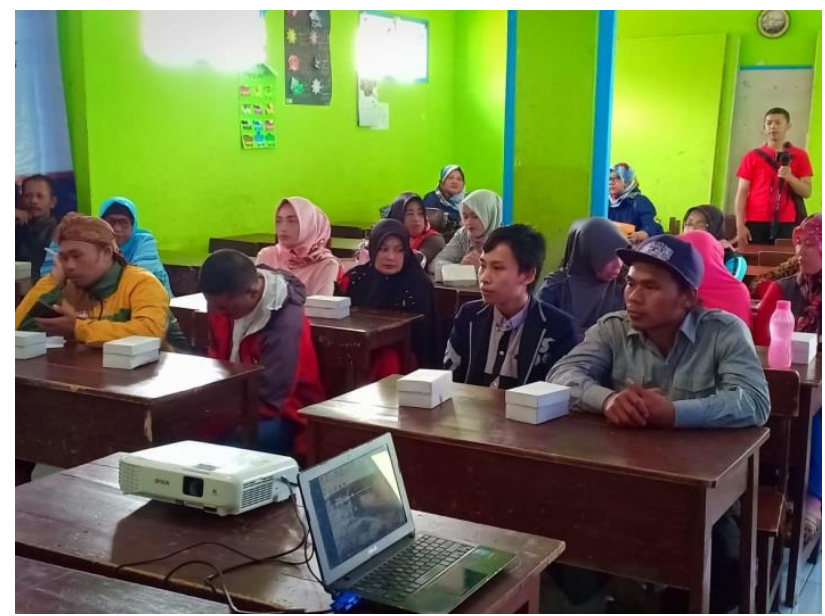

Gambar 2. Peserta Pelatihan Kewirausahaan UKM Desa Warnasari

Dalam memotivasi Pelaku Usaha dapat diperkenalkan secara teoritis mengenai entrepreneurship (kewirausahaan) (Silvia Herawaty, 1998:27) "Kewirausahaan adalah semangat, sikap, perilaku dan kemempuan seseorang dalam menangani usaha dan/atau kegiatn yang mengarah kepada upaya mencari, menciptakan, menerapkan cara kerja, teknologi dan produk baru dengan meningkatkan efesiensi dalam rangka memberikan pelayanan yang lebih baik a yang berfungsi sebagai inner dan/atau memperoleh keuntungan yang lebih efisiensi dalam rangka memberikan pelayanan yang lebih baik dan/atau memperoleh keuntungan yang lebih besar.

Wirausaha :
- Orang yang mengetahui Peluang dan memanfaatkanya

- Menurut Ciputra: wirausaha seseorang yang mampu merubah sampah dan rongsokan menjadi emas

- Motivasi : kemauan untuk berbuat sesuatu.

Motivasi seseorang tergantung kekuatan motifnya (Ciputra 2009:62).

Motif : kebutuhan, keinginan, dorongan, desakan hati yang membangkitkan dan mempertahankan gairah individu untuk mengerjakan sesuatu

Mengapa motivasi ada dal am diri individu?

1. Kebutuhan hidup

2. Kenyataan hidup

Strategi menjadi wirausaha: (Dindin Abdurrohim: 2018)

1. Melihat peluang: pelaku usaha harus bisa melihat dan mencari kebutuhan apa yang belum terpenuhi di masyarakat;

2. Menilai peluang: menganalisa, menghitung, dan menilai peluang yang akan dating harus didasarkan pada berbagai jurnal yang ada;

3. Memilih peluang: harus bisi memilih dan menetukan atau memutuskan apa usaha baru yang akan diambil atau dilaksanakan;

4. Melaksanakan peluang: eksekusi atau kemampuan untuk menghasilkan nilai tertinggi dari sebuah kesempatan yang diambil, membutuhkan kombinasi unik dari kreativitas, semangat, ketekunan, focus, tanggung jawab, perencanaan, kecerdasan dan energi.

\section{KESIMPULAN DAN SARAN}

\section{Kesimpulan}

Hasil dari Pengabdian Kepada Masyarakat ini dapat disimpulkan bahwa pelaku usaha di Desa Warnasari Kecamatan Pangalengan Kabupaten Bandung dapat merespon secara positif dalam memperoleh wawasan baru, 
mengetahui dan meningkatkan motivasi dalam menjalankan usahanya baik untuk memulai usaha, mengembangkan usaha dan meningkatkan kesejahteraan hidup keluarga dalam memenuhi kebutuhan masyarakat.

Hasil pembelajaran yang dapat diambil dalam menjalankan usaha, membutuhkan sistem yang terintegrasi yang saling terkait satu dengan yang lainnya. yakni dalam menjalankan usaha dibutuhkan komitmen yang tinggi dari pemilik usaha beserta jajaran nya agar perusahaan tersebut dapat berjalan secara optimal.

Pelaku usaha dapat mengelola usahanya dengan baik dan mempunyai motivasi yang tinggi dalam berwirausaha dengan mengembangkan potensi yang dimiliki baik potensi dirinya semangat untuk berwirausaha dan juga potensi sumber daya alam yang ada di daerah setempat. Yang pada akhirnya dapat membangun kekuatan UMKM khususnya di Desa Warnasari Kecamatan Pangalengan dan umumnya di Wilayah Daerah Kabupaten Bandung. Sehingga tercapainya kesejahteraan masyarakat Indonesia secara adil dan merata dalam meningkatkan perekonomian negara.

\section{Saran}

1. Para pelaku usaha di Desa Warnasari diharapkan dapat memanfaatkan dan mengolah potensi sumber daya alam yang ada (hasil bumi/perkebunan, perikanan dan peternakan).

2. Sebaiknya pelaku usaha dapat meningkatkan kreativitas dan inovasi dalam menghasilakan produk untuk memenuhi kebutuhan masyarakat.

3. Memperluas jaringan usaha agar semakin meningkatkan penjualan/pemasaran pada akhirnya dapat meningkatkan pendapatan
Adhi Prasetyo, (2001) Smart Guide Jualan Online, Protelon, Jakarta

Buchari Alma, (2015) Manajemen Pemasaran dan Pemasaran Jasa, Alfabeta, Bandung.

Ciputra, Quantum Leap, Entrepreneurship: mengubah masa depan bangsa dan masa depan anda, Universitas Ciputra Entrepreneurship Center, 2009.

Danang Sunyoto, (2013) Dasar-dasar Manajemen Pemasaran, Konsep, Strategi dan Kasus, Jakarta

Dindin Abdurrohim (Materi Kuliah Kewirausahaan 2018)

Eddy Soeryanto S. (2009) Entrepreneurship Menjadi Pebisnis Ulung, Kompas Gramedia. Jakarta

Irham Fahmi, (2017) Manajemen Produksi dan Operasi, Alfabeta, Bandung.

Kotler Philip dan Kevin Keller, (2008) Manajemen Pemasaran, Edisi ketiga, jilid satu, Penerbit Erlangga,Jakarta.

Moko P. Astamoen, (2005) Entrepreneurship Dalam Perspektif Kondisi Bangsa Indonesia, Alfabeta, Bandung.

Silvia Herawaty, Kewirausahaan, IPWI Jakarta, 1998.

Stanton William,(1988) Prinsip Pemasaran, Jilid 1, Edisi ke-7, dialihbahasakan oleh Sadu Sundaru, Erlangga, Jakarta.

Veithzal R. dkk (2014) Manajemen Sumber Daya Manusia Untuk Perusahaan dari Teori kePraktek, Edisi ke-3, Rajawali Pers.

Pedoman Pengabdian Masyarakat Edisi XII Kemen Ristekdikti, 2018.

\section{DAFTAR REFERENSI}

